\title{
Attracting High School Students to Engineering by Adapting a National Collegiate Competition
}

\author{
Laura P. Ford, Christi L. Patton \\ University of Tulsa
}

\begin{abstract}
$\underline{\text { Abstract }}$
We have modified the Chem-E-Car Competition held by the American Institute of Chemical Engineers at regional and national collegiate conferences and invited local high schools to compete. Our goal is to interest high school students in chemical engineering. We will hold our third High School Chem-E-Car Competition in April 2005.

Recruiting results from the first and second years will be presented in the paper with third year data added for the oral presentation. We are targeting chemistry and engineering classes. We hope to catch students in their junior years, before they have decided what college to attend. The junior- and senior-level participants will be examined for application to the University of Tulsa, as engineering majors and particularly as chemical engineering majors. The students will also be surveyed for future plans, specifically their chosen universities and majors. The effectiveness of the competition as a recruiting tool will be evaluated.
\end{abstract}

\section{$\underline{\text { Introduction }}$}

We have taken a national collegiate competition offered by a professional society and modified it for use at the University of Tulsa (TU) as a recruiting tool for chemical engineering. The national competition is the Chem-E-Car Competition sponsored by the American Institute of Chemical Engineers (AIChE). The rules of their competition are available at their website ${ }^{1}$. The students design and build a shoebox-sized car that is powered by a chemical reaction. The car must be able to carry a range of water loads and travel a range of distances. Poster presentations are included in the competition to ensure that safety concerns are met and that the cars meet the regulations. The water load and target distance are announced just one hour before the race. The goal is to be the closest to the target distance while carrying the designated water load. The competition has been going for six years at both the national and regional level. The national competition is quite stiff with the winning cars often landing within a foot of the approximately 90-ft target distance.

We simplified the AIChE competition for our high school competition ${ }^{2}$. Changes were made mostly to minimize the mechanical aspects of the competition and to enable us to hold the competition in our college's building. Significant changes are:

- smaller maximum car size

- shorter target distance

- no water load

- commercial batteries as power supply 
- track for the race course

- longer time limits, and

- teacher/advisor design involvement.

The complete rules and a scoresheet for the poster session are available at the website for the competition $^{3}$. The competition includes prizes for poster presentation, creativity, consistency, and first through third places in the race.

We made several changes in the competition between the first and second years, and made additional modifications for the third year. In the first year of the competition, we supplied an optional model car kit for each team. The kits did not work well, so we did not supply them for the second year. Even though the first year rules specified no spills of any liquids besides water, several cars spewed acidic or basic solutions. For the second year we added a $10 \mathrm{ft}$ penalty to any car that released anything besides gases or water. The second year cars were much cleaner, and the students even fussed about the one car that did release water onto the track. Changes for the third year include a rule about nudging cars that run into the siderail of the track and requiring that the car travel the minimum target distance to be considered for the consistency prize.

We have several goals with our high school competition. One of our frequent recruiting problems is that students have no idea what chemical engineering might be. If they don't know what it is, they won't consider it as a major. The teachers are frequently not much more informed. One goal is to introduce the students and teachers to chemical engineering by forcing them to use chemical engineering concepts. The contest requires them to use a chemical reaction and to calibrate it carefully by varying the reactant quantity or the reaction kinetics. The second goal is to attract students to the University of Tulsa. We want them to have a good time at the competition and to associate that good time with the University, in hopes that it will make them more likely to apply to and attend the University.

We want to reach the students in their junior year or before. The competition is in April, and most seniors have already decided where they will be going to college by then.

\section{Methods}

We have several different methods that we have used to gather information about the students. We do not ask for student names with registration for the competition. Often, the number of teams from a school changes after the registration deadline two months before the competition, and the composition of the teams shifts in that time frame as well. We wait until the competition itself to gather names and information from the students.

The first information form is the "Pizza Ticket". The sequence of events for the competition is poster session, distance announcement, lunch, car race, and awards ceremony. The high school students fill out the pizza ticket and turn it in as they get their food. The pizza ticket primarily allows us to get the demographic information that we are interested in but it also ensures that the high school participants get lunch before the University student assistants. The pizza ticket from 2004 is shown in Figure 1. The pizza ticket from the 2003 race did not prompt the students for 


\section{University of Tulsa High School Chem-E-Car Competition Demographics Survey}

Fill this out as your ticket for two pizza slices, fruit, a cookie, and a drink!

1. Your name

2. Your year in school Freshman Sophomore Junior Senior

3. Your school

4. What do you plan to do after graduating from high school (please be as specific as your plans are: vo-tech, job, college, probable major or field)?

Figure 1. Pizza Ticket from 2004

major, and the majority of the students simply answered "college". Results from the 2004 tickets were much more specific.

At the end of the competition, we hand each teacher/advisor a packet of evaluation forms for both the students and the teacher. The evaluation form asks for suggestions for improvement on the rules, facilities, and poster session. It also asks a series of questions that we use to judge the effectiveness of recruiting students to engineering:

- Did you enjoy the Chem-E-Car Competition?

- Have you ever considered engineering as a career field?

- Has participating in the Chem-E-Car Competition made you more or less likely to consider engineering as a career field?

- Has participating in the Chem-E-Car Competition helped you better understand some of what engineers do?

A postage-paid envelope is included for the teachers to mail the evaluations back to us.

One problem in evaluation is that we want to know what career decisions the juniors from the previous year's competition have made. Remember that we do not have home addresses, phone numbers, or email addresses for the vast majority of these students. Postage-paid postcards (Figure 2) were sent to these students at their high school,

Dear
Thank you for participating in the High School Chem-E-Car
Competition at the University of Tulsa in either 2003 or 2004. We
gathering information to evaluate the effectiveness of the competiti
Please answer the following questions and mail the postcard back to
Thank you for your help!
Post-graduation plans: job, vo-tech, college/university, other
If you plan to attend college or university, please list
and the college or university
$\quad$ your planned major

Figure 2. Postcard for follow-up with the previous year's juniors. 
in care of the teacher who advised the students in the previous year's competition.

We also sent the list of participants from both years who graduated in either 2003 or 2004 to our admissions office and asked the admissions office which students had expressed interest in TU, applied to TU, and/or will be attending TU. Expressing interest in TU included actions such as attending an Open House, visiting campus, sending test scores, corresponding with an admissions counselor, responding to a search brochure, applying for admission, or requesting information. We have similar data from the admissions office on average application rates from each school that has participated in our competition.

\section{$\underline{\text { Results and Discussion }}$}

Table 1 presents the registration and race day participation figures for the 2003 and 2004 competitions. Significant attrition occurs between registration and the competition. Some schools simply don't get the cars built in time, but others have had scheduling conflicts beyond their control (school field day and endof-year testing). The average team size decreased from the first year to the second, and the average number of teams per school

\begin{tabular}{|l|l|c|c|}
\hline \multicolumn{4}{|c|}{ Table 1. Registration and Attendance Data } \\
\hline \multirow{2}{*}{ Schools } & Registered & 2003 & 2004 \\
\cline { 2 - 4 } & Participated & 7 & 10 \\
\hline \multirow{2}{*}{ Teams } & Registered & 12 & 7 \\
\cline { 2 - 4 } & Participated & 10 & 14 \\
\hline \multirow{3}{*}{ Students } & Registered & 88 & 131 \\
\cline { 2 - 4 } & Expected & 73 & 71 \\
\cline { 2 - 4 } & Participated & 54 & 63 \\
\hline
\end{tabular}
increased.

We sent 36 postcards to the juniors from the 2003 competition and asked them what they would be doing after graduation this year. Fifteen cards were returned. We were relying upon the teachers from last year to get the postcards to students whom they may not even have in class anymore, so a low return rate was not too surprising. Of the cards returned to us, one student came to TU and another student will be majoring in chemical engineering elsewhere. (It should be noted that one of our 2004-2005 freshmen had participated in the competition with Union High School but never received a postcard from his teacher. His case is not included in these statistics.) If one in fifteen $(\approx 7 \%)$ of the area high school students who took chemistry came to $\mathrm{TU}$, or became chemical engineers anywhere, we would be thrilled. But the total number of responses is too small to give these figures statistical validity.

Evaluation forms were sent to the schools that participated in the race and to schools who had registered but did not participate. None of the schools that registered but did not attend returned evaluation forms. Numerical data from the evaluation forms are presented in Table 2. The numbers do not always add up to the total number of evaluations received because a few students did not answer a question or they said "both" or "no effect". The students overwhelmingly enjoy the competition, and they feel that they better understand what engineers do after the competition. The students who had already considered engineering as a career were more likely to consider it after the competition. The students who had not considered engineering previously switched from more likely to less likely in the two years of the competition. We do not have enough data yet to know why this has happened. The goal is to increase the awareness of 
engineering as a career option and not necessarily to encourage all students to become engineers because not everyone has the abilities/strengths for engineering.

\begin{tabular}{|c|c|c|c|c|}
\hline \multirow{3}{*}{$\begin{array}{r}\text { Competition Year } \\
\text { Evaluations received }\end{array}$} & \multirow{2}{*}{\multicolumn{2}{|c|}{$\begin{array}{c}2003 \\
36\end{array}$}} & \multirow{2}{*}{\multicolumn{2}{|c|}{$\begin{array}{c}2004 \\
36\end{array}$}} \\
\hline & & & & \\
\hline & Yes & No & Yes & No \\
\hline $\begin{array}{l}\text { 1. Did you enjoy the Chem-E-Car } \\
\text { Competition? }\end{array}$ & 36 & 1 & 35 & 1 \\
\hline $\begin{array}{l}\text { 2. Has participating in the Chem-E-Car } \\
\text { Competition helped you better understand } \\
\text { some of what engineers do? }\end{array}$ & 34 & 1 & 28 & 6 \\
\hline \multirow[t]{2}{*}{$\begin{array}{l}\text { 3. Have you ever considered engineering } \\
\text { as a career field? }\end{array}$} & 11 & 25 & 16 & 19 \\
\hline & More & Less & More & Less \\
\hline $\begin{array}{l}\text { 4a. (If YES to \#3) Has participating in } \\
\text { the Chem-E-Car Competition made you } \\
\text { more or less likely to consider } \\
\text { engineering as a career field? }\end{array}$ & 9 & 1 & 13 & 1 \\
\hline $\begin{array}{l}\text { 4b. (If NO to \#3) Has participating in the } \\
\text { Chem-E-Car Competition made you more } \\
\text { or less likely to consider engineering as a } \\
\text { career field? }\end{array}$ & 17 & 6 & 5 & 11 \\
\hline
\end{tabular}

We also sent the list of juniors and seniors from the 2003 competition and seniors from the 2004 competition to the admissions office to find out how many had expressed interest in TU. The admissions office also had data on how many students from each school have applied to or enrolled at TU. These results are presented in Table 3. The total number of graduates for each school was taken from the school's website or estimated by dividing the enrollment by the number of grades. The application and enrollment rates are averages over four years, except for the Tulsa School of Arts and Sciences (TSAS) which is averaged over two years since it is a new charter school. One homeschooled student was omitted from the analysis. The Union and Will Rogers absolute numbers are very small partly because 2004 was their first year of participation. 


\begin{tabular}{|l|c|c|c|c|c|c|c|c|}
\hline \multicolumn{7}{|c|}{ Table 3. Students who were interested in TU, applied to TU, or enrolled at TU (2004) } \\
\cline { 1 - 7 } \multicolumn{1}{|c|}{ School } & Students & $\begin{array}{c}\text { Chem-E-Car Competition } \\
\text { Interested }\end{array}$ & $\begin{array}{c}\% \\
\text { Applied }\end{array}$ & $\begin{array}{c}\% \\
\text { Enrolled }\end{array}$ & Graduates & $\begin{array}{c}\% \\
\text { Applied }\end{array}$ & $\begin{array}{c}\% \\
\text { Enrolled }\end{array}$ & School Setting \\
\hline Bartlesville & 17 & 35 & 6 & 6 & 424 & 3.7 & 1.2 & Small city \\
\hline Drumright & 7 & 29 & 14 & 14 & 30 & 2.2 & 0.8 & Small town \\
\hline Kellyville & 16 & 44 & 13 & 6 & 84 & 3 & 1.5 & Small town \\
\hline TSAS & 15 & 67 & 20 & 20 & 45 & 26.7 & 18.9 & Metropolitan \\
\hline Union & 2 & 50 & 0 & 0 & 911 & 7.3 & 2.8 & Metropolitan \\
\hline Will Rogers & 2 & 100 & 0 & 0 & 256 & 3 & 1 & Metropolitan \\
\hline Total & 59 & 47 & 12 & 10 & 1750 & 6 & 2.5 & \\
\hline
\end{tabular}

Nearly half of the students who participated in the competition expressed some interest in TU. Chem-E-Car Competition students not in the metropolitan area applied and enrolled at TU at a higher rate than their cohort. Metropolitan students who participated in the competition applied at a lower rate than their cohort and enrolled at rates at or below the rates of their cohorts. Overall, the students participating in the competition apply and enroll at higher rates than their combined high school classes. The absolute number of students who have participated in the competition and graduated, however, are too small for strong statistical conclusions about the effectiveness of our recruiting competition.

In comparing our recruiting results to those from the entire graduating class, we need to keep in mind that our competition is likely attracting college-bound students who are not representative of their entire graduating class. The students participating in the competition are taking either chemistry or an engineering class or are in the school's science club. This probably makes them more inclined to attend college, although current state graduation requirements include Biology I and two more science classes. This science requirement can be met with Earth Science and Physical Science classes, but more students now take Chemistry I in order to meet graduation requirements.

We can use some nationwide data for comparison. In 2002, 13,425,000 students were enrolled

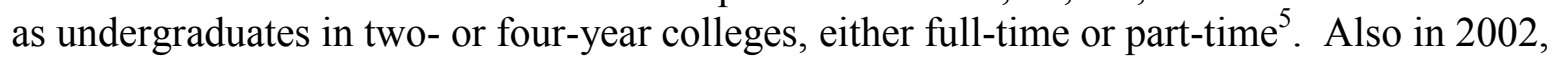
there were 398,439 students (3\%) enrolled in undergraduate engineering majors (full- and parttime $)^{6}$. Chemical engineering majors numbered 23,368 to make up $0.2 \%$ of the total college population or $6 \%$ of the engineering enrollment (the year was not explicitly stated for this data, but other data from this source were for 2002$)^{7}$.

When we combine the postcard results with the admissions office results, we have one student in chemical engineering (2\%) and two students total in engineering $(3 \%)$. The chemical engineering result for our recruiting event is very nice, but the data are too limited to make a claim for success. The results for recruiting students to our University look more promising. The 2005 competition is scheduled for April 26. At this time, registrations are running slightly higher than in previous years with at least one new school participating. The June 2005 presentation will include updated information from the most recent competition and any other newly acquired admissions data. 


\section{$\underline{\text { Literature Cited }}$}

1. http://students.aiche.org/events/chemecar.asp. Accessed June 9, 2004.

2. C.L Patton and L.P. Ford, Chemically Powered Toy Cars: A Way to Interest High School Students in a Chemical Engineering Career, Proceedings of the 2003 American Society for Engineering Education Annual Conference and Exposition (2003) 596.

3. http://www.ce.utulsa.edu/CarCompetition/Spring2004/CarComp2004.html. Accessed June 9, 2004.

4. Oklahoma State Law, Title 70 O.S. § 11-103.6.

5. U.S. Census Bureau, School Enrollment - Social and Economic Characteristics of Students: October 2002 Detailed Tables, January 9, 2004.

6. Michael Gibbons, Databytes: Undergraduate Engineering Education by the Numbers, ASEE Prism 13:7 (2004) 20.

7. Michael Gibbons, Databytes, ASEE Prism 13:2 (2003) 19.

\section{Biographical Information}

\section{LAURA P. FORD}

Dr. Ford has been an Assistant Professor of Chemical Engineering at the University of Tulsa since January 1999. She earned chemical engineering degrees from Oklahoma State University (BS) and the University of Illinois at Urbana-Champaign (MS and $\mathrm{PhD}$ ). Her research is in dry etching of metals and metal alloys and in remediation of soils contaminated by produced fluids.

\section{CHRISTI L. PATTON}

Dr. Patton is Applied Assistant Professor of Chemical Engineering at The University of Tulsa. She received her B.S. in Chemical Engineering from Texas A\&M University and her M.S. in Applied Mathematics and her Ph.D. in Chemical Engineering from The University of Tulsa. She is currently involved in applying fuel cells and reformers to hybrid-electric vehicles. 